\title{
Effect of Corporate Governance on Firm Performance on Modarba Companies of Pakistan: A Case Study of Top 5 Companies
}

\author{
Chaudhry Abdullah Imran Sahi \\ Lecturer, Lahore School of Accountancy and Finance, The University of Lahore, Lahore, Pakistan \\ chabdullahsahi@yahoo.com \\ Zubair Aslam \\ School of Accounting and Finance \\ University of central Punjab, Lahore Punjab, Pakistan
}

\begin{abstract}
In the decades or so there is many global financial crises that capture the attention of corporate governance in the whole world it is moral duty conform by law and showing ethics.so the country like Pakistan a developing country can used as a tool for financial performance. The study shows the impact of corporate Governance on firm performance of modarba companies of Pakistan .we can take top 5 companies of the industry from the period of 2011 to 2015 .we can take board size, CEO duality, board committees, and board independence, as independent variable and ROA and ROE as dependent variable.

After the research of that we find that overall corporate governance variable have significant impact on firm performance. There is no relationship between board size and all dependent variable. Board independence has positive and strong relationship on all variable However, there is negative correlated between CEO duality and all dependent variable but significantly related to ROA
\end{abstract}

Keywords: corporate governance, financial performance, firm performance

\section{Introduction}

Every organization want become leader of the market but only those organization is consider leader who can make perfection in all department. In every organization human resource is consider as a backbone of the company. Not only backbone of a company but also play a vital role in development and sustainability. In a situation when competitor is difficult then it tell us way who to play the game. Corporate governance now becomes an important part in the last two decades. In recent years we can see many accounting scandal and frauds that can affect the biggest companies of the world. In the modern world we can say that corporate governance play a vital role in firm sustainability in long term and increasing interest of researcher and policy maker through analysis and practices. A literature can also show the many accounting fraud in the past

By using as a tool corporate governance supplier of capital save their investment for yourself. (Shleifer and Vishny, 1997).Shareholder are the people who take part in contributing the money and special corporate governance cycle help them to apply control over the management of the company for the maximization of the shareholder wealth. The BOD act as an agent forreducing the agency cost (Fama and Jensen, 1983).

This research shows the empirical analysis to test the effect of corporate governance phenomena on firm performance on listed top 5 modarba companies of Pakistan for the last five year 2011-

The current issue and full text archive of this journal is available at www.jraspublications.org/index.php/JRAS/issue/archive Journal of Research in Administrative Sciences (JRAS)

VII(I), 1-5, ISSN: 2664-2433 
Effect of Corporate Governance on Firm Performance on Modarba Companies of Pakistan: A Case Study of Top 5 Companies

Chaudhry Abdullah Imran Sahi, Zubair Aslam

2015 firm performance is calculated through profitability that is return on asset and Return on equity .corporate governance is calculated through Board Structure And Ownership Structure and it can be sub categorize as Board Independence and Board Size for board Committee and CEO Duality for Ownership Structure

\section{Literature Review}

Link between board of director and Firm performance

Board of director are representative of the all the shareholder and stakeholder of the company. The company delegated with the responsibility of checking the performance and activities of the top management to ensure they work for the best interest of the shareholder. Sometime board vested our power and not done their responsibilities

The board of a company is one of the cores internal corporate system (Brennan, 2006). The problem of structure of the board of director as a corporate governance system has received significant attention in last decade from studies market practices and regulators. It continues to take attention because theory provides different view on impact of board structure on the control and performance of firm on the other hand empirical evidence is unsatisfying.

\section{Effect of Board Size on Firm Performance}

This is the most important feature of the board structure. After review the literature we saw that two different views on factors effect on board size on firm value the first say larger board is effective in performance of the company. And there is positive impact of board size with the firm value (Ehikioya, 2009;Klein, 2002;Dalton et al.,1999).it is seem that strong arguments in support of larger board size.one thought is larger board gave a verity it is obviously that when there is more people in the pool then their knowledge is more and person from every field is make the decision more strong and reliable for the company (Dalton et al., 1999; Pearce and Zahra, 1992). When there is more people involve in the company then more external linkages(Goodstein et al., 1994).

The other school of thought is who say larger board show less efficiency in the performance of the company. Many studies shows there is negative relationship between size and performance of company(Yermck, 1996;Eisenberg et al.,1998;Cheng, 2008 Bonn ey a.,2004).A study show there is negative association between size with firm under some critical factor. Many scholar say large board is ideal. On the other hand in larger board there is lack of communication between board member (Jensen, 1993) the biggest problem of larger board is small group and all having own interest that will cause less efficient decision. It is also a problem that decision is taken quite slowly.

\section{Effect of board independence on firm performance}

Board independence mean board is take decision without any pressure of any person within the organization. When nonexecutive director are part of board then board is more independent (John and subnet, 1998) but how it is connected with company performance but the problem is here is that executive director is more close with the actives of the organization then the nonexecutive director however the non-executive director work as a consultant or advisory role for the maximize the shareholder wealth and protect the Interest of shareholder and stakeholder of the company (fama, 2000).but some researcher found there is no significant relation between nonexecutive director and company performance (Bhabat and Black, 2002).

It shows that the effectiveness of a board depends on the mixture of Executive and non-executive director of the company.

\section{Effect of CEO Duality on firm performance}

It is quite controversial that companies $\mathrm{CEO}$ and chairman is a same person or not. There are some example that shows advantages and disadvantages of change person of CEO and chairman like combination of two position $\mathrm{CEO}$ and chairman makes greater power to the CEO (Brickley, et al 1997).we can see that CEO take charge of chairman after good performance among collage and say it is the reward for the good performance in the conflict of outside directors.in this situation separate the CEO and chairman However, giving the duties of Ceo and chairmen to one person its quite hard for the board to replace a poorly performing CEO, which show the less flexibility of a board and result decrease in performance (Goyal et al, 2002).

In CEO-chairman duality, CEO is performing dual role of chairman and CEO there are two schools of thought. First say if there is same person in CEO and chairman than he make own paper for exams. Segregation of duties leads to (1) Independence establishes (2) Chairman gave order to CEO (3) Monitoring OF board activities (Baysinger and Hoskisson, 1997).

But on the other side there is some researcher who believes that $\mathrm{CEO}$ and chairman should be same person. If there is same person on CEO and chairman position than they find (1) strong leadership (2) strong internal efficiency (3) end of conflict between CEO and chairman (Davis, Schoorman and Donaldson, 1997)

\section{Conceptual Framework}

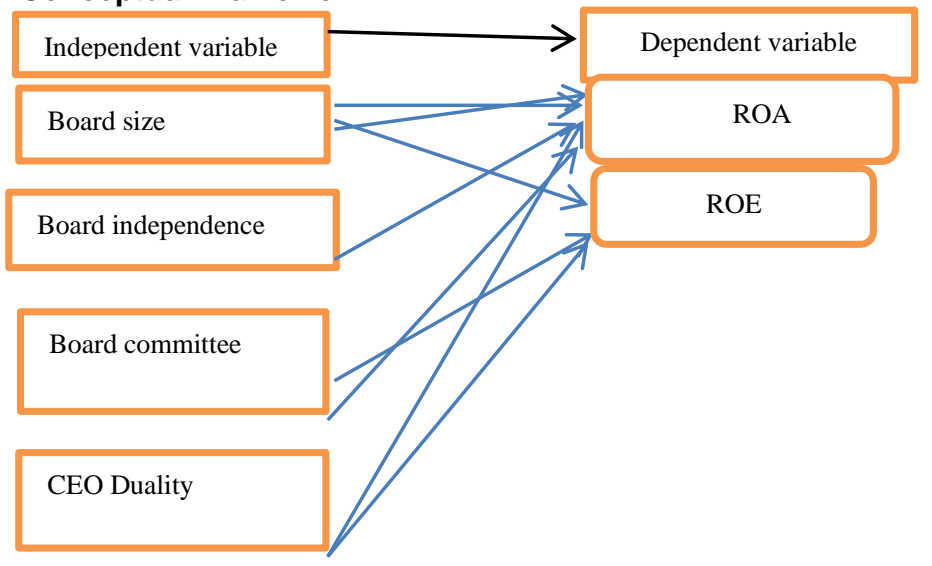

Hypotheses

H1: Board size has impact on ROA On modarba companies

$\mathrm{H} 2$ : Board committee has impact on ROA on modarba companies

H3: Board independence has impact on ROA on modarba companies

H4: Ceo duality has impact On ROA on modarba companies

H5: Board size has impact on ROE on modarba companies

H6: Board committee has impact on ROE on modarba companies

H7: Board independence has impact on ROE on modarba companies

H8: Ceo Duality has impact on ROE on modarba companies

\section{Reach Design}

The purpose of this study is to know the effect the corporate governance on firm performance in modarba companies of Pakistan in the last 5 years. This section tells us about research method and tests the hypotheses that written above the qualitative approach which is most well-known method to determine the relationship between variables

\section{Sampling Data Sourcing and Collection}

This research is conducted on top 5 listed modarba companies of Pakistan.it is qualitative study. The sampling period is decided between 20011-2015 we can used secondary data collected from their websites. The sample size is 5 because of it is a case study. The cross sectional data can be used. The companies which we include in the study they have debt in capital.

\section{Variable Descriptions}

Corporate governance is considered as independent variable and firm performance is chose as dependent variable. The proxy measure of corporate governance is board size, board independence, board committee and Ceo duality. The firm performance is measure through return on asset (ROA) and return on equity (ROE). 
Effect of Corporate Governance on Firm Performance on

Modarba Companies of Pakistan: A Case Study of Top 5

Companies

Chaudhry Abdullah Imran Sahi, Zubair Aslam

Measurement of Variable

\begin{tabular}{|c|c|c|}
\hline Variable & Name & Measurement \\
\hline BOSIZ (IV) & Size of board & Total member in board \\
\hline BOIND (IV) & Board Independence & $\begin{array}{l}\text { Non-executive } \\
\text { member over total } \\
\text { member }\end{array}$ \\
\hline BOCOM (IV) & Committees in board & Total committee \\
\hline CEODUL (IV) & Same person & $\begin{array}{l}\text { Chairman or ceo if one } \\
\text { person than } 1 \text { if } \\
\text { change person than } 0\end{array}$ \\
\hline ROA(DV) & Return & Income divide by \\
\hline
\end{tabular}

Journal of Research in Administrative Sciences Volume VII, Issue I, 2018, 1-5

\begin{tabular}{lll}
\hline & & book value of asset \\
ROE(DV) & Return Equity & $\begin{array}{l}\text { Income divide by } \\
\text { book value of equity }\end{array}$ \\
\hline
\end{tabular}

\section{Descriptive}

The analysis is starts with examine the basic characteristics of the data like mean, median, maximum value ,minimum value,standard deviation, skewness and kurtosis etc. in given below we discuss the these thing of the data period from 2011 to 2015

\begin{tabular}{ccccccc}
\hline & Board committee & $\begin{array}{c}\text { Board } \\
\text { independence }\end{array}$ & Board size & Ceo duailty & Return on asset $\begin{array}{c}\text { Return } \\
\text { on equity }\end{array}$ \\
\hline Mean & 2.268761 & 0.642207 & 7.998255 & 0.214660 & 0.068425 & 0.120096 \\
\hline Median & 2.000000 & 0.666667 & 7.000000 & 0.000000 & 0.050870 & 0.103470 \\
Maximum & 5.000000 & 1.000000 & 16.00000 & 1.000000 & 3.081646 & 3.596965 \\
\hline Minimum & 0.000000 & 0.000000 & 3.000000 & 0.000000 & -1.281 & -6.357 \\
Std. Dev & 1.090816 & 0.249668 & 2.290524 & 0.410945 & 0.184432 & 0.420155 \\
\hline Skewness & 0.374928 & -0.526174 & 0.806070 & 1.365698 & 8.656515 & -3.819 \\
\hline Kurtosis & 2.678095 & 2.380004 & 3.469537 & 2.931870 & 142.2993 & 118.9355 \\
\hline
\end{tabular}

The mean of the board committee is 2.25 and the minimum value is 0 and maximum is 5 so there is week presence of compliance. The mean of Ceo duality is 0.21 with the maximum of 1 and minimum of 0 .so there is different person on most of the sample companies.board independence have a mean of 0.639.its range from 0 to 1 .that shows there is non-executive member in the board. Board size has a mean of 7.97 with the minimum of 3 and maximum value is 16 .if the size of bod is greater than 5 that mean that is good.

The average of ROA is $6.5 \%$ and the average of ROE is $11 \%$.both show the positive number that is good during the year 2011 to 2015. If it is show negative sigh than that is economic down fall.

Dependent Variable: ROE

Method: least Square

date: $05 / 12 / 017$

Sample: 20112016

duration: 5 year

observations: 576

\begin{tabular}{|c|c|c|c|c|}
\hline Variable & Coefficient & Standard E & T-Stat & Pro. \\
\hline Constant & 0.285181 & 0.145925 & 1.95429 & 0.0000 \\
\hline BODCOMM & 0.013262 & 0.010860 & 1.22125 & 0.2225 \\
\hline BODINDEP & 0.199892 & 0.099271 & 2.01360 & 0.0445 \\
\hline BODSIZE & 0.002139 & 0.002893 & 0.73950 & 0.4599 \\
\hline CEODUALY & 0.045885 & 0.024081 & -1.90542 & 0.0572 \\
\hline $\mathrm{R}^{2}$ & 0.625921 & Mea(DV) & & 0.120218 \\
\hline Adj. $R^{2}$ & 0.013628 & S.D. (DV) & & 0.419283 \\
\hline Standard Error & 0.416416 & $\mathrm{Ak}$ & & 1.097815 \\
\hline Sum resid & 98.66599 & Schwarz & & 1.150754 \\
\hline Logarithm & -309.1708 & H-Q criter. & & 1.118461 \\
\hline F-stat & 2.324074 & $\mathrm{D}-\mathrm{W}$ stat & & 1.786656 \\
\hline Probility & 0.031658 & & & \\
\hline
\end{tabular}

This test is used to check the problem of is there is a problem of multicollinearity or not to know the relationship between the all dependent variable. This problem will be occur when two or more independent are strong correlated with each other.so it is essential to check the multicollinearity. 
Effect of Corporate Governance on Firm Performance on Modarba Companies of Pakistan: A Case Study of Top 5 Companies

Chaudhry Abdullah Imran Sahi, Zubair Aslam

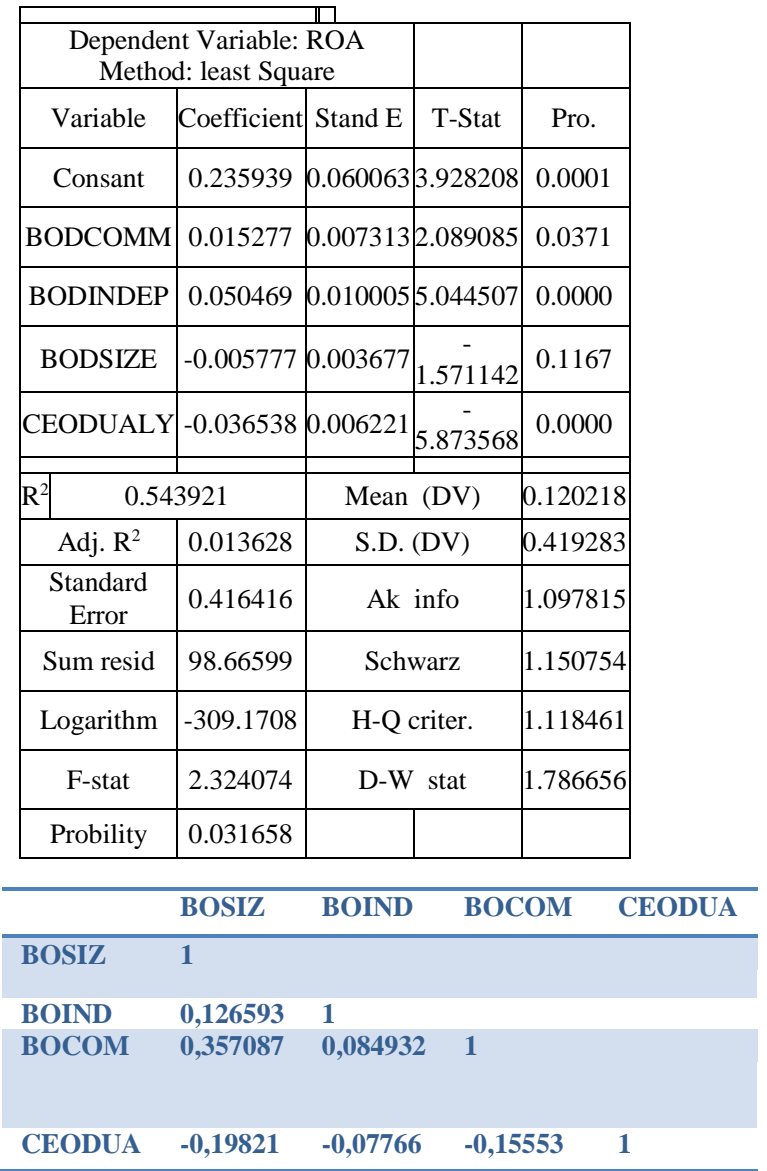

As you see in the above table Board size have relationship with three variable two of them show positive relation which is board independence the value is 0.12659 and board committee the value is 0.35708 and the negative correlated with Ceo duality the value is 0.127.board independence have positive relationship wity committee the vaue is 0.0849 and negative relationship with Duality the value is -0.07766 .committee have negative relationship with duality the value is -0.155 .

Board size and board committee is the strongest correlation. There is positive number which is good sign. The lowest correlation is between committee and duality in negative way.

\section{Regression Analysis}

\section{Explanation}

The first output (E- view) shows the result of regression for ROE the first line shows the relationship between independent variable board size board committee board independence and ceo duality with dependent variable ROE.it can also tell the magnitude and direction of the measure. The result shows that there is positive impact of all independent variable on ROE.

The second output (E-view) shows the result of regression for ROA. The first line show the relation of independent variable with dependent variable ROA.it also shows the direction and magnitude of measures. There is positive impact between board committee and independence with ROA and there is negative impact between board size and CEO duality with ROA. The value of $\mathrm{R}$ square is 0.54 it can explain $54 \%$ which is acceptable.

\section{Model}

$\mathrm{ROA}=\alpha+\beta 1 *$ BODCOMM $+\beta 2 *$ BODINDEP $+\beta 3 *$ BODSIZE $+\beta 4 *$ CEODUALY

$\mathrm{ROE}=\alpha+\beta 1 * \mathrm{BODCOMM}+\beta 2 * \mathrm{BODINDE}+\beta 3 * \mathrm{BODSIZE}$ $+\beta 4 *$ CEODUALY

\section{Summary of regression}

\begin{tabular}{llll}
\hline $\begin{array}{l}\text { Dependent } \\
\text { variable }\end{array}$ & $\begin{array}{l}\text { Independent } \\
\text { variable }\end{array}$ & $\begin{array}{l}\text { Relationship } \\
\text { variable }\end{array}$ & $\begin{array}{l}\text { Significant } \\
\text { value }\end{array}$ \\
\hline ROA & BOSIZ & Negetive & 0,1167 \\
ROE & BOSIZ & Positive & 0,4599 \\
ROA & CEODUA & Negetive & 0,0572 \\
ROE & CEODUA & Negetive & $0,0000^{* *}$ \\
ROA & BOIND & Negetive & 0,0572 \\
ROE & BOIND & Negetive & $0,0000^{* *}$ \\
ROA & BOCOM & Positive & 0,0371 \\
ROE & BOCOM & Positive & 0,2225 \\
\hline
\end{tabular}

\section{Recommendation and Conclusion}

The study show the effect of corporate governance on top 5 modarba companies 2011-2016. To measure corporate governance variable are bored size board independence, board committee, CEO duality are chosen.to measure firm performance ROA and ROE is selected.

The effect of board independence is found the most significant variable since $t$ is positively to all measure however good corporate governance practice decrease corporate issue with the help of non-executive directors in the monitoring and auditing process the large amount of committee is increase the profit than who have less board committee In the last if the person of Ceo and chairman is not same than they can earn more profit rather than same persom as the show in the result there is negative correlated with all measure to protect interest of shareholder and maximize the shareholder wealth

\section{Reference}

i. Fama, E. F., \& Jensen, M. C. (1983). Separation of ownership and control. Journal of Law and Economics, 26(2), 301-325.

ii. Shleifer, A. and Vishny, R.W. (1986), "Large shareholders and corporate control", Journal of Political Economics, Vol. 94 No. 3, pp. 461-88.

iii. Jensen, M.C. and Meckling, W.H. (1976), "Theory of the firm: managerial behaviour, agency cost and ownership structure"', Journal of Financial Economics, Vol. 3 No. 4, pp. 305-60

iv. Erickson, J., Park, Y.W., Reising, J. and Shin, H.H. (2005), "Board composition and firm value under concentrated ownership: the Canadian evidence', Pacific-Basin Finance Journal, Vol. 13 No. 4, pp. 387-410

v. Ruigrok, W., Peck, S.I. and Keller, H. (2006), “Board characteristics and involvement in strategic decision making: evidence from Swiss companies", Journal of Management Studies, Vol. 43 No. 5, pp. 1201-26. S

vi. Ehikioya, B.I. (2009), "Corporate governance structure and firm performance in developing economies: evidence from Nigeria"', Corporate Governance, Vol. 9 No. 3, pp. 231-43.

vii. Klein, A. (2002), "Audit committee, board of directors characteristics, and earnings management", Journal of Accounting and Economics, Vol. 33 No. 3, pp. 375-400

viii. Dalton, D.R., Daily, C.M., Johnson, J.L. and Ellstrand, A. (1999), "Number of directors and financial performance: a meta-analysis", The Academy of Management Journal, Vol. 42 No. 6, pp. 674-86

ix. Pearce, J.A. and Zahra, S.A. (1992), "Board composition from a strategic contingency perspective", Journal of Management Studies, Vol. 29 No. 4, pp. 411-38.

x. Goodstein, J., Gautam, K. and Boekar, W. (1994), "The effect of board size and diversity on strategic change", Strategic Management Journal, Vol. 15 No. 3, pp. 241-50.

xi. Yermack, D. (1996), "Higher market valuations of companies with a small board of directors", Journal of Financial Economics, Vol. 40 No. 2, pp. 185-211.

xii. Jensen, M.C. (1993), "The modern industrial revolution, exit and the failure of internal control systems", Journal of Finance, Vol. 48 No. 3, pp. 831-80. 
Chaudhry Abdullah Imran Sahi, Zubair Aslam

xiii. John, K. and Senbet, L. W. (1998). "Corporate Governance and Board Effectiveness" Journal of Banking and Finance

xiv. Fama, E.F. (2000)."Agency problems and the theory of the firm”.Journal of Political Economy, 88(2, April): 288-307

xv. Bhagat, S. and Black, B. (2002). "The Non-Correlation between Board Independence and LongTerm Firm Performance", Journal of Corporation Law, 27(2), 231-273.

xvi. Baums, T. (1994).Corporate Governance in Harmonysystem and Recent Developments, inAspects of corporate Governance, Stockholm: Jurist

xvii. Brickley, J. A., Coles, J. L. and Jarrell, G. (1997). Leadership structure: Separating the CEO and Chairman of the Board. Journal of Corporate Finance

xviii. Goyal, V. and Park.C. (2002). "Board Leadership Structure and CEO Turnover," Journal of Corporate Finance, 8: 49-66

xix. Baysinger, B. andHoskisson, R. (1997). The composition of boards of directors and strategic control: Effects on corporate strategy. Academy of Management Review,

xx. Davis, J., Schoorman, F. and Donaldson, L. (1997).Toward a stewardship theory of management.Academy of Management Review, 22, 1, 20-47. 